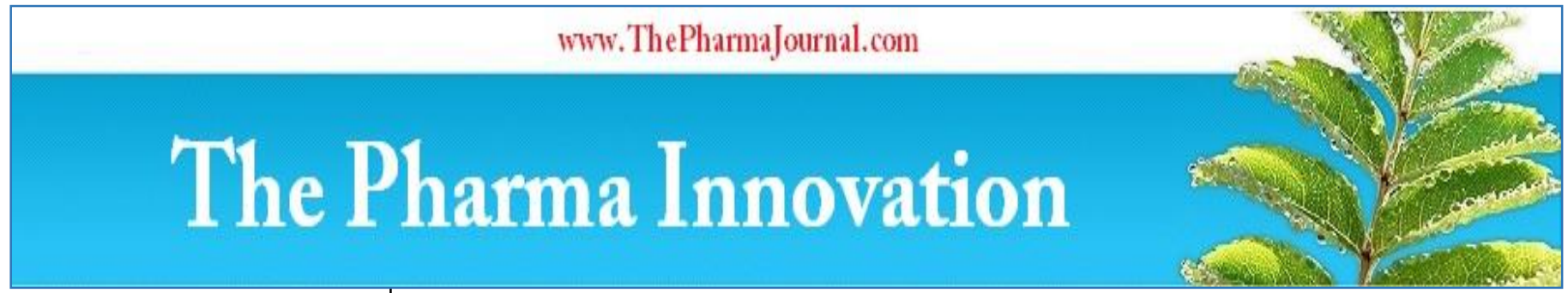

ISSN (E): 2277 - 7695

ISSN (P): 2349-8242

NAAS Rating: $\mathbf{5 . 0 3}$

TPI 2021; 10(2): 621-625

(C) 2021 TPI

www.thepharmajournal.com

Received: 10-12-2020

Accepted: 16-01-2021

Lalita Garg

Division of Livestock Product Technology, ICAR-Indian

Veterinary Research Institute,

Izatnagar, Bareilly, Uttar

Pradesh, India

Kamal Kumar

Division of Extension Education,

ICAR-Indian Veterinary

Research Institute, Izatnagar,

Bareilly, Uttar Pradesh, India
Corresponding Author:

Lalita Garg

Division of Livestock Products

Technology, ICAR-Indian

Veterinary Research Institute,

Izatnagar, Bareilly, Uttar

Pradesh, India

\section{Dairy sector in Pre, during COVID-19 and Post pandemic periods: A review}

\author{
Lalita Garg and Kamal Kumar
}

DOI: https://doi.org/10.22271/tpi.2021.v10.i2i.5742

\begin{abstract}
Dairy farming is essential not only as a source of income but also as a reservoir of protein, supplementary nutrition, fertilizer, fuel, and a store of wealth for millions of households across the country. The dairy sector has been a tool of inclusive development in our country, as the distribution of dairy animals is more equitable than landholding. The COVID-19 pandemic-induced lockdown has created a vital adverse impact on different sectors, including that of agriculture and allied sectors in India and several other countries. The crisis is severe in countries like India where dairy farming is one of the most essential sources of sustenance and regular income for 60 million rural households of which 80 percent are landless, small, and marginal farmers. The COVID-19 pandemic has opened up the opportunity for the dairy industry to benefit as large sections of consumers may shift from meat-based to dairy-based protein. COVID-19 has made people more aware of the need to adopt a healthy diet. The government should work upon increasing the procurement base of the organized sector, creating storage and bulk milk chilling infrastructure, promoting value addition, and encouraging clean milk production. The dairy sector is more resilient compared to other sectors and according to various industry reports signs of recovery are observed. Being more equitable in distribution the dairy sub-sector is the new growth dynamo of the agriculture and allied sectors.
\end{abstract}

Keywords: COVID-19 pandemic, livestock sector, dairy sector, post pandemic, agriculture

\section{Introduction}

Livestock is an integral component of the farming system in India and contributes immense support to the overall development of the agriculture sector in the country. It plays a vital role in the life of farmers. Dairy farming is essential not only as a source of income but also as a reservoir of protein, supplementary nutrition, fertilizer, fuel, and a store of wealth for millions of households across the country. Over the period, the contribution of the livestock segment in the Agriculture sector has been showing steady improvement that attributes to its importance in the Indian economy. The dairy sector has been a tool of inclusive development in our country, as the distribution of dairy animals is more equitable than landholding - while small and marginal farmers own only 45 percent of farmland, they own about 75 percent of bovines $\left(\text { Rath }^{\mathrm{b}}, 2020\right)^{[18]}$. Only 30 percent of the liquid milk is processed into various dairy products like ghee, butter, cheese, curd, ice-cream, milk powder, etc. (Bhandari and Ravishankara, 2020) ${ }^{[3]}$. The COVID-19 pandemic-induced lockdown has created a vital adverse impact on different sectors, including that of agriculture and allied sectors in India and several other countries. The crisis is severe in countries like India where dairy farming is one of the most essential sources of sustenance and regular income for 60 million rural households of which 80 percent are landless, small, and marginal farmers. Thus, even a small drop in the growth of the dairy sector significantly influences a large part of our population. The present review aimed to explain the status of the dairy sector during the Pre, COVID-19, and Post pandemic scenario, which is has been one of the emerging sectors in recent years.

\section{Dairy sector in pre COVID-19 time}

The livestock sector is one of the fastest growing segments of the agricultural economy in India. It contributes nearly 28.63 percent of the total value of agriculture GDP and accounts for about 4.2 percent of the total GDP (Economic Survey, 2020-21) ${ }^{[11]}$. The overall growth of livestock sector shows increasing trends and is around 8.24 per cent and this has been achieved despite the fact that the investment in this sector was not substantial (Economic Survey, 202021) ${ }^{[11]}$. During 2019-20, livestock sector contributed 198.4 million tonnes of milk, 63.02 billion eggs, 42.99 million $\mathrm{kg}$ wool, and 4.83 million tonnes of meat. 
India ranks first in the world in milk production, which went up from 17 million tonnes in 1950-51 to 198.4 million tonnes in 2019-20 (Economic Survey, 2020-21) ${ }^{[11]}$. The per capita availability of milk has also increased from 112 grams per day in 1968-69 to 407 grams in 2019-20 (Economic Survey, 202021) ${ }^{[11]}$. The average yield per animal per day for exotic/crossbred is $7.95 \mathrm{~kg}$ per day and for indigenous/nondescript is $3.01 \mathrm{~kg}$ per day (GoI, 2019) ${ }^{[10]}$. The milk production from exotic/ crossbred cattle has increased by 8.7 percent and for indigenous/ non-descript cattle it has increased by 5.7 percent compared to previous year (GoI, $2019)^{[10]}$. The milk production from buffalo also increased by 6.4 percent in comparison to previous year (GoI, 2019) ${ }^{[10]}$.

As shown in Figure 1 the largest contribution in the milk production of the country is of buffalo (49\%) followed by cow (48\%) and goats (3\%). The average milk yield of the cross bred/ exotic cattle is $7.95 \mathrm{~kg} / \mathrm{animal} / \mathrm{day}$ whereas for non-descript/ indigenous cattle is $3.01 \mathrm{~kg} / \mathrm{animal} / \mathrm{day}$. As shown in Figure 2, the contribution of livestock sector to total GVA is on increasing trends.

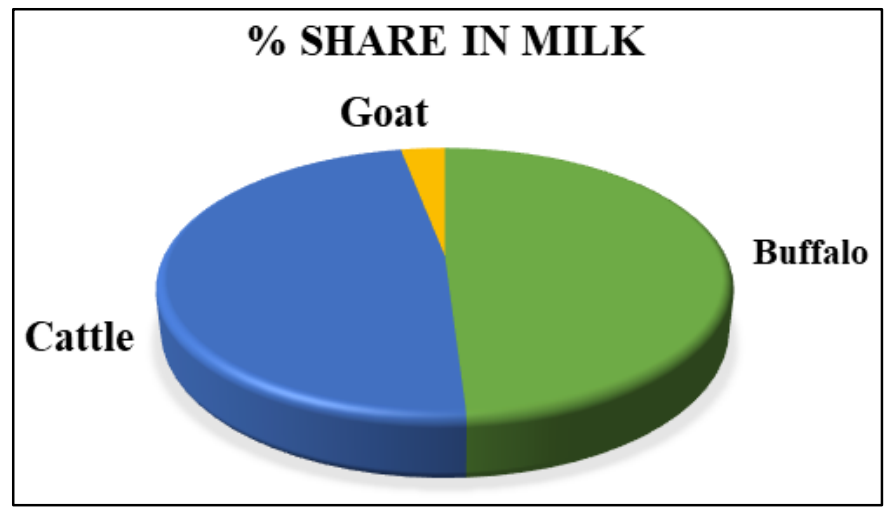

Fig 1: Share of dairy species in total milk production of India

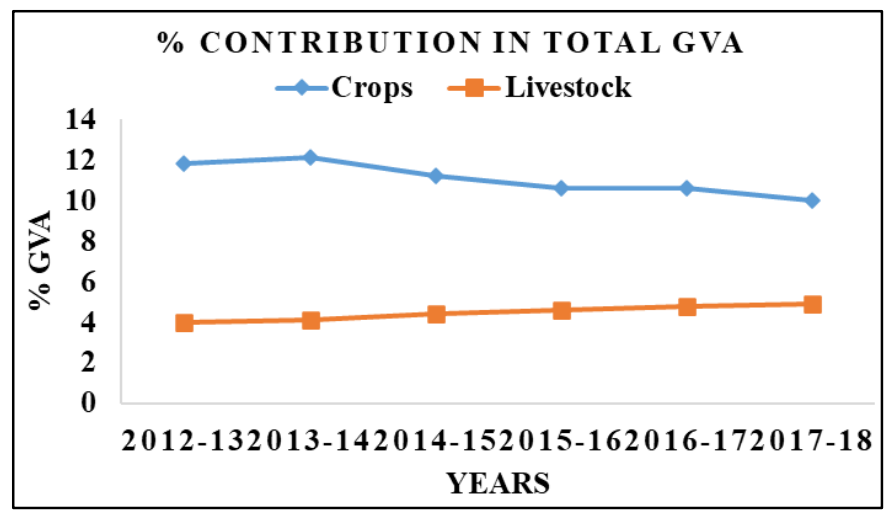

Fig 2: Trends in the share of livestock and crop sector in total GVA

\section{During COVID-19 Pandemic}

The COVID-19 pandemic has massively influenced agricultural sectors around the world (Kerr 2020, Zhang et al., 2020) ${ }^{[15,22]}$. Among the sectors that have harmed the most is the dairy industry as dairy products are highly perishable and depend on interspersed and time-sensitive supply chains (BBC News 2020; Marshall 2020) ${ }^{[2,16] .}$

The impact of COVID-19 induced lockdown on the dairy sector in the country has been extraordinary. It is further projected that the impact might continue to be long-standing and can have a great bearing on the livelihood opportunities, employment, and overall economy of the dairy sector (Biswal, et al., 2020) ${ }^{[4]}$.
Based on initial information, supply chains of livestock and livestock products were completely interrupted due to months-long lockdowns. As the market machinery collapsed, the survival of all livestock keepers is now under threat. Major challenges for the sector include a reduction in the purchasing power among consumers and decreasing prices of livestock products. Besides, accessibility to markets and transport was among the biggest challenges for dairy farmers. Inter-country and intra-country trade chains have meddled as well.

As per the survey conducted in Gujarat, the significant challenges encountered by the two milk unions during the pandemic were workforce management, surplus milk collection, decreased demand of milk and milk products, safety and health of animals as well as farmer members from the virus, transportations of milk from district cooperative societies to processing plants and distribution of processed milk and milk products to the consumers (Parmar and Mishra, 2020) ${ }^{[17]}$.

The 15 percent of the Dairy revenue comes from out-of-home sales which completely was on standstill. Dairies were procuring more milk to help the farmers thus left with a surplus of milk. There was a decline in procurement prices of milk whereas a surge was witnessed in the price of skim milk powder (Business Today, 2020) ${ }^{[6]}$.

All the above-mentioned hurdles resulted in total disruption of the economy and survival of the dairy farmers. Without income, livestock herders are not in a position to afford feed and fodder, which further leads to the starvation of animals. These are concerns that will create a long-term impact on the sustainability of the sector. Even access to veterinary care for the livestock was becoming increasingly difficult.

\section{Crisis on dairy product demand and supply}

Despite the enhanced demand for dairy products as consumers stock up shelves for potential lockdowns and containment zones, keeping up with that demand and ensuring the supply chain has not been an easy feat (Edairynews, 2020) ${ }^{[7]}$. Exports were hampered because of slowing demand for dairy, not because of less consumer use, but because shipments had to go through more protocols and procedures to get to some locations around the world. Villages and markets were closed after the announcement of lockdown, restricting the mobility of dairy farmers and access to markets for the sale of their products. Restrictions on transport disrupted supply and trade. Pastoralists were not in a state to seize market access and hence their informal trade channels collapsed. This has created huge livelihood losses across the country (Dadas, 2020) ${ }^{[9]}$. Dairy farmers were facing problems in procuring inputs as well as in disposing of their output.

As far as output was concerned farmers reported that daily milk production has declined by approximately $10-15$ percent due to the limited availability of feed and fodder (Bhandari and Ravishankara, 2020) ${ }^{[3]}$. Commercial dairy farms recorded an 8-10 percent decline in their daily milk sales (Bhandari and Ravishankara, 2020) ${ }^{[3]}$. Dairy farmers who were directly delivering the milk to consumer door-steps have been affected less as compared to the ones supplying it to the restaurants, dine-in outlets, or private processors.

Due to a fall in demand, farmers received lower milk prices. Estimation based on newspaper reports indicated that the average milk prices have declined by $35-40$ percent for most of the dairy farmers across the country. The nationwide lockdown prevented institutional sales of VAP to hotels and 
restaurants, which account for almost 20 percent of the organized dairy segment's revenue (Agrospectrum) ${ }^{[8]}$. Moreover, logistical challenges and consumer's reluctance in consuming frozen products like ice creams, flavored milk, and yogurt during the pandemic have adversely impacted sales in the first quarter, which is supposed to be a peak-demand season (Agrospectrum). Information collected by National Dairy Development Board (NDDB) from the dairy cooperatives shows a decline in daily liquid milk sales by dairy cooperatives by about 15 percent in the Covid-19 lockdown period between March 1-15 and April 8-14, and a drop in the proportion of sales to procurement by about 8.8 percent during the same period $\left(\right.$ Rath $\left.^{\mathrm{b}}, 2020\right){ }^{[20]}$.

\section{Product loss/Income loss}

To prevent the spreads of COVID-19 pandemic, many restaurants, school, café and companies which receive milk from the producers were temporarily shut down across the continents. So, many milk producers were faced with interruption of the market chain (Chimde, 2020) ${ }^{[5]}$.The study has found that during the COVID-19 lockdown there has not only been a decrease of income from dairying but also the uncertainty of income for the dairy farmers (ToI, 2020) ${ }^{[18]}$. This has had serious implications for the milk producers as milk production is mostly carried out as a complementary enterprise along with crop production (ToI, 2020) ${ }^{[18]}$. Because of crisis, the dairy farmers were unable to repay their dues. Disruption appears to have affected the unorganized private actors significantly as they have a larger share of merchandise in their sales portfolio corresponded to the dairy cooperatives (Ratha ${ }^{\mathrm{a}}$, 2020) ${ }^{[19]}$. It was, therefore, truly rational that the areas/milk sheds where private players had a stronger presence, milk got averted to the dairy cooperatives as a result of which, producer price also got quashed due to the disproportion between demand and supply (Ratha $\left.{ }^{\mathrm{a}}, 2020\right)$ [19].

\section{Dairy processing industries}

The dairy processing industry in India is quite small in comparison to the huge quantum of milk produced in the country and the total share of cooperatives and private processing units is only 12-15 percent (Bhandari and Ravishankara, 2020) ${ }^{[3]}$. Most of the milk transit in liquid form and only a smaller proportion is converted into dairy products. Though the major dairy cooperatives like Amul were able to ensure maximum procurement most of the private players faced problems in procurement and proper transportation of milk. Another major issue was a shortage of packaging material and limited processing capacity. The problem was relatively less in the availability of other inputs like labor, sugar, fuel, and lubricants. The key concern for dairy processors was a fall in demand due to the shutdown of restaurants, hotels, sweet shops, roadside eateries, offices, and schools owing to which they had to keep their plant idle. Demand for liquid milk fell sharply than other products like ghee, paneer, curd, etc. Some of the dairy processing units reported an increase in the demand for paneer during the lockdown period. There was not much increase in the input cost for processing units. Only transportation cost showed an upward trend for them while some of them got milk at a lower cost. Thus, the fall in demand remained a major culprit for them. Along with this, they were not able to get timely payments from their customers which also reduced their efficiency.

\section{Livestock feed and fodder}

Feed and fodder accounting for almost 60 percent of the total cost of milk production are the significant inputs in dairy farming. With decreasing landholding size, dairy farmers are now more dependent on the market for meeting their requirements of feed and fodder which are sourced from different parts of the country (Bhandari and Ravishankar, 2020) ${ }^{[3]}$. The farmers were facing problems in getting cattle feed mainly because the cattle feed industry has temporarily shut down its production units due to the uncertain supply of raw materials, labor shortage, and transportation problems. To combat the problem of cattle feed scarcity the National Dairy Development Board (NDDB) has started reformulating the cattle feed by replacing the raw materials in short supply with locally available constituents (Bhandari and Ravishankar, 2020) ${ }^{[3]}$.

\section{Farm workforce absenteeism}

The dairy sector in India is mostly unorganized which is mainly dominated by the system of family farming, so labor was not a major concern for these unorganized businesses. Labor is a major input particularly for commercial/ organized dairy farms and food processing industries as these are laborintensive industries. But because of the COVID pandemic either they migrated to their native towns or unable to reach their workplaces. This led to a temporary closure of industries hurting the production and thus the dairy economy.

\section{Veterinary services}

Though there was not much difficulty concerning the availability of medicines for the dairy animals but veterinary services like artificial insemination, suffered badly. The farmers will have to face the consequences of missed artificial insemination for a longer time. This will increase the rearing cost of non-pregnant animals for dairy farmers.

\section{Input cost}

Movement of inputs and credit are the other components bearing the major brunt. If we look into the cost aspect, there was more or less a rise in the prices of all the inputs. As reported by Bhandari and Ravishankara (2020) ${ }^{[3]}$ there was a big hike in the prices of cattle feed which increased by Rs. $150-200$ per quintal whereas the prices for dry fodder raised by $80-100$ rupees per quintal. Although prices of feed and fodder were in acceleration during the last year too due to adverse climate and floods in various parts of the country, Covid-19 made it more hurtful for the dairy farmers.

\section{After lockdown}

Despite all the disruptions during the lockdown, the demand for milk as well as other dairy products has increased for several reasons including a growing interest in home baking and an increased number of people working from home (PRNewswire, 2020) ${ }^{[13]}$. There has also been an extended interest in shelf-stable milk products such as UHT Milk, Milk Powder, and Evaporated Milk (PRNewswire, 2020) ${ }^{[13]}$. To boost milk production, promote exports, and enhance employment by supporting MSMEs and private businesses through aid in processing and value addition in the dairy sector, Finance Minister announced an Animal Husbandry Infrastructure Development Fund of ₹15,000 crores (The Federal, 2020) ${ }^{[1]}$. This will support strengthening the dairy sector, which has endured the COVID-19 challenges despite all odds. 
To enhance the marketing of milk and other dairy products, many dairy businesses, initiated door-step delivery through mobile carts, vans, and e-commerce platforms, etc. All these measures encouraged stabilized milk vending and opening up opportunities to utilize e-commerce. Many progressive dairy farmers transformed their surplus milk into khoa, paneer, and ghee, etc., and sold it to the local markets through informal channels (Indian Cattle, 2020) ${ }^{[12]}$. All these measures helped in sustaining the dairy industry.

\section{Post COVID scenario}

Various inferences are drawn from the available government reports, industry reports, newspapers, and experts' opinions on the COVID-19 pandemic and its impact on the dairy industry and what will be the post-pandemic scenario. These are discussed as follows

\section{- Value addition is the need of the hour}

During the COVID pandemic, there was surplus milk procurement by cooperatives despite the "lean season" when milk production normally sees a decline. The challenge of surplus milk was managed properly by district milk unions, via converting it into value-added dairy products such as butter, cheese, ghee, and milk powder (Parmar and Mishra, 2020) ${ }^{[17] .}$

- Creation of local milk grids or local milk collection and chilling centers

There is a need to create local milk grids in Punjab and linking those grids to vendors, organized dairies as well as milk processors across Punjab and adjoining milk deficient regions of Jammu and Kashmir, and Rajasthan to help the dairy industry to deal with the Covid-19 like situation.

\section{- More procurement of milk by the organized sector}

The livestock market is underdeveloped, and the supply chain is poor. Dairy cooperatives and private dairies procured only 20 percent milk, while 32 percent was sold in the unorganized sector (Kumar et al., 2021) ${ }^{[14]}$. Milk procurement through dairy cooperatives tends to be more elastic than vendor-driven dairy markets and losses to the dairy farmers are higher in vendor-driven markets during the Covid-19 pandemic (ToI, 2020) ${ }^{[18]}$. To help the dairy cooperatives the Ministry of Fisheries, Animal Husbandry, and Dairying declared "interest subvention on working capital loans for the dairy sector"(Parmar and Mishra, 2020) [17].

- Possible change in food habits and increased health consciousness

The covid-19 pandemic has thrown up the opportunity for the dairy industry to benefit as large sections of consumers may shift from meat-based to dairy-based protein. Covid-19 has made people more aware of the need to adopt a healthy diet $\left(\text { Rath }^{\mathrm{a}}, 2020\right)^{[19]}$.

- Faster growth rate in the dairy sector, than the agriculture sector thus scope for expansion

- FMD and HS vaccination program launched by the government will lead to increased production and more export opportunities for the dairy sector as product competitiveness in the international market will be increased

- Structural transformation of the dairy cooperatives with the help of NDDB will increase their efficiency and procurement capacity

- There is utmost need to create storage facility and bulk milk chilling facilities

\section{Conclusion}

The dairy sector is an emerging sub-sector of the allied sector and has been witnessing a compound annual growth rate of more than 5 percent in the last five years. The livestock sector is one of the fastest-growing segments of the agricultural economy in India. It contributes nearly 28.63 percent of the total value of agriculture GDP and accounts for about 4.2 percent of the total GDP. The impact of COVID-19 induced lockdown on the dairy sector in the country has been extraordinary. It is further projected that the impact might continue to be long-standing and can have a great bearing on the livelihood opportunities, employment, and overall economy of the dairy sector. Based on initial information, supply chains of livestock and livestock products were completely interrupted due to months-long lockdowns. The COVID-19 pandemic has opened up the opportunity for the dairy industry to benefit as large sections of consumers may shift from meat-based to dairy-based protein. COVID-19 has made people more aware of the need to adopt a healthy diet. The government should work upon increasing the procurement base of the organized sector, creating storage and bulk milk chilling infrastructure, promoting value addition, and encouraging clean milk production. The dairy sector is more resilient compared to other sectors and according to various industry reports signs of recovery are observed. Being more equitable in distribution the dairy subsector is the new growth dynamo of the agriculture and allied sectors.

\section{References}

1. All you need to know: Third tranche of Centre's stimulus package https://thefederal.com/covid-19/all-you-need-toknow-third-tranche-of-centres-stimulus-package/ accessed on 15 February 2021

2. BBC News. Coronavirus: Why Canada dairy farmers are dumping milk. [2020-04-06]. https://www.bbc.com/news/ world-us-canada-52192190 accessed on 15 February 2021

3. Bhandari G, Ravishankara KM. Implications of COVID19 for Indian Dairy Sector. Food and Scientific Reports 2020;1:43-46.

4. Biswal J, Vijayalakshmy $\mathrm{K}$, Rahman $\mathrm{H}$. Impact of COVID-19 and associated lockdown on livestock and poultry sectors in India, Veterinary World, 2020;13(9):1928-1933.

5. Chimde L. Review on impacts of COVID-19 pandemic on life animals and dairy product processing industries of the world. Insights Vet Sci 2020;4:018-024.

6. Coronavirus impact: Dairy industry faces $30 \%$ dip in demand

https://www.businesstoday.in/current/corporate/coronavir us-impact-dairy-industry-faces-30--dip-indemand/story/400517.html accessed on 18 February 2021

7. Coronavirus is the latest challenge to face dairy industryhttps://edairynews.com/en/coronavirus-is-thelatest-challenge-to-face-dairy-industry-71168/ accessed on 15 February 2021

8. Covid-19 adversely impacts dairy industry: CRISIL reporthttp://agrospectrumindia.com/news/50/826/covid19-adversely-impacts-dairy-industry-crisil-report.html accessed on 20 February 2021

9. Dadas DR. Covid-19 decimated livestock sector; shattered livelihoods of millions. https://thewotrblog.wordpress.com/2020/06/18/covid-19- 
decimated-the-livestock-sector-shattered-livelihoods-ofmillions/ accessed on 15 February 2021

10. Government of India. Basic Animal Husbandry Statistics 2019 http://dahd.nic.in/circulars/basic-animal-husbandrystatistics-2019 accessed on 30 January 2021

11. Government of India. Economic Survey 2020-21 https://www.indiabudget.gov.in/economicsurvey/doc/vol 2chapter/echap07_vol2.pdf accessed on 10 February, 2021

12. How COVID-19 Could Benefit the Dairy Industry https://www.indiancattle.org/covid-19-benefit-dairyindustry/ accessed on 15 February 2021

13. Impact of COVID-19 on the Dairy Market.https://www.prnewswire.com/newsreleases/impact-of-covid-19-on-the-dairy-market-milkand-cream-posts-279-growth-301047556.html accessed on 19 February 2021

14. Kumar K, Garg L, Singh RK, Chander M.

15. Kerr W A. The COVID-19 pandemic and agriculture: Short- and long-run implications for international trade relations. Canadian Journal of Agricultural Economics 2020;68:225-229

16. Marshall A. Why farmers are dumping milk, even as people go hungry. [2020-04-23]. https://www.wired.com/story/whyfarmers-dumping-milkpeople-hungry/ accessed on 15 February 2021

17. Parmar Pankaj and Mishra Harekrishna. Dairy sector handled the lockdown well https://www.thehindubusinessline.com/opinion/dairysector-handled-the-lockdown-well/ article32717902.ece accessed on 10 February 2021

18. Punjab: Create milk grids to help dairy sector emerge from COVID shadow. https://timesofindia.indiatimes.com/city/chandigarh/creat e-milk-grids-to-help-dairy-sector-emerge-from-covidshadow-says-study/articleshow/78690416.cms accessed on 10 February 2021

19. Rath Dilip ${ }^{\mathrm{a}}$. A new White Revolution: How COVID-19 could benefit the dairy industryhttps://www.financialexpress.com/opinion/anew-white-revolution-how-covid-19-could-benefit-thedairy-industry/1942634/ accessed on 17 February 2021

20. Rath Dilip ${ }^{\mathrm{b}}$. New agri-reforms: Dairy is the farm sector's growth engine, 2020 https://www.financialexpress.com/opinion/new-agrireforms-dairy-is-the-farm-sectors-growthengine/2134857/?fbclid=IwAR1y8ApFuSF7EJBMjU14h SKnS1KjzA4_-aXJQDczcn2GHF8i4vJ8vhdudcE accessed on 20 February 2021

21. Stephenson M, Shutske J. Six impacts of COVID-19 on Agriculture 2020.

22. Zhang S, Wang S, Yuan L, Liu X, Gong B. The impact of epidemics on agricultural production and forecast of COVID-19. China Agricultural Economic Review 2020;12:409-425. 